\title{
Latin America and the Caribbean and a New Global Order: Facing Global and Regional Challenges
}

\author{
A. Serbin \\ Coordinadora Regional de Investigaciones Económicas y Sociales, \\ Lavalle, 1609, Buenos Aires, Argentina
}

For citation: Serbin A. Latin America and the Caribbean and a New Global Order: Facing Global and Regional Challenges. Vestnik of Saint Petersburg University. International Relations, 2019, vol. 12, issue 2, pp. 139-152. https://doi.org/10.21638/11701/spbu06.2019.202

Latin America and the Caribbean as a region faces an intricate process of transition. This process is conditioned by the changes currently ongoing in the international environment, by a reconfiguration of the regional political map and by an exhaustion of the attempts to build regionalization and political consensus of the preceding decade, associated at the time to the boom of commodities and the rise of populist and leftist governments. To the difficulties faced by CELAC - where the construction of consensuses by an atomized region vis a vis external actors becomes extremely difficult, it should be added the evident weakening of the ALBA with the exhaustion of the Venezuelan capacity to nourish with oil resources the cooperation that sustains the Bolivarian scheme and a crisis underway in UNASUR where - particularly as a result of the Venezuelan crisis and the paralysis of the institution - six of its member countries (half of its total membership) have questioned the functioning of the agency and threaten to withdraw their membership. Although the Venezuelan crisis may be the epicenter of this regional situation and its impact - possibly polarizing - on the crossroads that are confronting regionalism and regional integration, introspection is not enough. The potential convergence of MERCOSUR with the Pacific Alliance, the redefinition of the external policies of its members as a result of electoral changes or the re-shaping of its domestic dynamics do not fully explain the current shift and it is necessary to combine it with the understanding of the pressures imposed by a changing global environment, where the crisis of globalization, the difficulties to build global governance, the weakening of multilateralism and the decline of the international liberal order are associated with the reconfiguration and diffusion of power worldwide, within a framework of a series of developments plagued by uncertainties and risks for the region. In this perspective, this article addresses the different dimensions of global transformations and its impact on the region and the challenges that the region faces in order to adapt to the changes in the current international environment.

Keywords: Latin America, Caribbean, international order, global governance.

\section{The crisis of globalization, global governance and the international liberal order: a preamble to an emerging global order}

The international system is undergoing a complex transition, with high levels of uncertainty and accelerated transformations, with tectonic changes that involve displacements and geo-economic and geopolitical reconfigurations at the global level ${ }^{1}$.

1 As one specialist points out in a recent article, in today's world "geoeconomic and geopolitical dynamics coexist, more or less intensely, delineating an unpredictable and fluctuating world scenario" [1].

(c) Санкт-Петербургский государственный университет, 2019 
The characteristics of this global transition affect Latin America and the Caribbean, and demand a better understanding of its dynamics and of the impact on the region and its capacity to shape a collective response. This transition is associated to the intertwining of a series of new and critical realignments in the international system.

One of these realignments is associated with the crisis of the globalization process and of the existing global governance design and, particularly, of the hegemonic model that sustained them [2], as we have known it up to now. Precisely, one of the main factors for the development and sustainability of the existing structure of global governance currently in crisis has been the economic environment in which it was built. An economic environment characterized by the intensification of a globalization process associated with processes of denationalization and transnationalization. Since the seventies trade flows, investment and financing accelerated; production was reshaped by post-fordist innovation combined with technological innovation that contributed to the configuration of a global market. As a result, global economic interdependence increased significantly while asymmetries and inequalities deepened. The emergence and development of globalization entailed risks and opportunities for the actors in the international system [3]. Within this framework, asymmetric interdependence and inequitable distribution of its benefits contributed to generating winners and losers of this process [4], particularly in those nations where the middle class grew but at the same time the levels of poverty expanded [2]. However, as pointed out in a 2004 report, the problems were not necessarily and exclusively associated with economic globalization, but were rooted in the deficiencies of its governance [5].

With the end of the Cold War, global governance emerged as a possibility to organize and manage global affairs multilaterally. In the economic sphere with the World Trade Organization (WTO) as a reference body but also with the Bretton Woods institutions (the International Monetary Fund, the World Bank); in the security field with the North Atlantic Treaty Organization (NATO) and in the international political sphere with the United Nations (UN) and its promotion of a universal and complex multilateralism, several mechanisms were set to contribute to the development of rules and norms to order the international system. Within this framework, global governance was conceived as "governance without government" - an intermediate state between the management of global problems through the traditional inter-state policy and the attempt to operationalize a world government $[6, p .62]$. The absence of a central authority in the international system implied, consequently, the need for collaboration and cooperation between different actors to develop common objectives, standards and practices in addressing global issues and providing global public goods $[7, \mathrm{p} .17]^{2}$.

The process to foster global governance pivoted on the values promoted by the West the creation and consolidation of international institutions and norms in accordance with international law, the promotion of human rights and democracy, and of economic liberalization and free trade, within the framework of a predominantly Westphalian

${ }^{2}$ Legler defines global governance as "the resolution of specific global problems through the creation of distinct transnational spheres of authority, each of which comprises a different group of actors and a particular institutional architecture" [8, p. 254], pointing out the little interest that has awakened its analysis among Latin American researchers and academics and highlighting that the G20, in which Argentina, Brazil and Mexico participate - and whose next meeting will be held in 2018 in Buenos Aires, can reactivate this interest [8, p. 266]. 
conception of the international system based on the interrelation between states, with the eventual participation of other actors $[9$, p. 13; 10].

On the other hand, globalization ${ }^{3}$ itself was buttressed by the worldwide development of transnational corporations (CTN) that contributed to boost economic liberalization and transnationalisation, sometimes in collusion or above the interests of state and national sovereignty $[11, \text { p. } 22-24]^{4}$. The growth and sustained development of emerging economies - and in particular of China with the comparative advantage of its labor force, of new paths of non-liberal capitalist development and of new power relations weakened the multilateral institutions. This weakening led some analysts to point out, particularly after the global financial crisis of 2008, to the return of rivalries between the great powers and to the resurgence of geopolitical competition $[12 ; 13]$, as the 'rule-based' system faced challenges and contestations. Within this framework, the globalization originally promoted by US hegemony and Western predominance began to benefit primarily China, which progressively began to dispute the benefits of this process [14, p. 55].

The new global dynamics associated with emergent economies - beyond the advent of the BRICS group (Brazil, Russia, India, China and South Africa) and the continuity (with some ups and downs) of the Atlantic alliance between the US and the European Union - was centralized progressively around the two most important powers - the US and the People's Republic of China (PRC), increasingly in competition. Although the US prevails as the hegemonic actor that, together with its Western allies, shaped the international liberal order after the Second World War and, especially after the end of the Cold War, the accelerated growth of China generated, together with the growth of other Asian actors, a gradual shift from the center of world economic dynamism from the Atlantic to the Asia Pacific. Paradoxically enough, this significant economic shift didn't happen from North to South - as predicted in the 70's - but from West to East [16].

With the emergence of new actors and the dispute over the benefits of globalization, not only the power relations established after the Second World War come into question, but also the stability of the international system. The legitimacy of the rules and values of global governance achieved in previous decades began to be questioned with the emergence of new institutions (BRICS, Asian Infrastructure and Investment Bank, the BRICS Bank) and norms. Actors such as China and Russia, among others, began to offer alternative political models to liberal democracy, while economic growth in the developing world accelerated on the basis of political alternatives that responded more to different variants of state capitalism than to democratic liberal models [17]. This transition made a particular impact on Western conceptions of sovereignty and human rights, by imposing conceptions of sovereignty that questioned the liberal cosmopolitan approach to the supremacy of human rights over the prerogatives of national sovereignty in domestic affairs (as it is the case of the Responsibility to Protect as an international norm [18]). The convergence of a series of tendencies associated with the emergence of new powers gave rise to a struggle for leadership in the process of shaping global governance, affecting

${ }^{3}$ I refer to the referential text [17] for a more detailed analysis of globalization.

4 As Actis and Busso point out, "Until the beginning of the second decade of the $21^{\text {st }}$ century, globalization brought gains for the hegemon. The large American companies controlled the most important link in the value chain (technological innovation and knowledge) relegating the production phase to third markets with comparative advantages in terms of wages. Thus, the most important income was shared among the American multinationals in addition to benefiting the US consumer via prices" [14, p. 54]. 
liberal social conceptions, paralyzing existing multilateral institutions and increasing their fragmentation and informalization [17].

The institutions traditionally established and dominated by the West entered into tension with the aspirations and strategies of new power centers. Globalization and globalism as its narrative began to be increasingly contested, both by the new international actors and by domestic political processes in the West. However, deeper contestations or attempts to overthrow the existing order didn't flourish. Rather, what tended to emerge is an order with competing multilateral projects, with different strategic objectives and distinctive leadership that generates new forms of geo-economic competition, in a framework in which the international liberal order enters into crisis $[19 ; 20]$. Thus, the international system becomes institutionally and politically more diversified and polycentric with higher potential for unrest and conflict [17]. Simultaneously, beyond the potential competition among the larger powers - the US and China, - it become prone to the development of regionalized cores and pockets under the emergence of an economic and geopolitical multipolar system. In this sense, the reinvigoration of various modalities of regional cooperation - particularly intense in the Global South since the end of the last century - gave rise to a regional activity in which different bilateral, subregional and regional economic and security issues emerged, generating in turn different efforts of regional governance [6, p. 61-62].

This new cycle led to an ongoing debate on the crisis of globalization, the development of a post-globalization (i.e. a globalization that is still developing, but with new features), a de-globalization, an alternative globalization ${ }^{5}$ or of a pots-liberal [15] or post-Western globalization of growing sino-centric accent [22], but with a proactive participation of emerging and re-emerging powers (Turkey, Iran, India, Russia) [23].

None of these states rejects the benefits provided by globalization. But, in essence, the process raises the possibility of a contradiction between the globalization process developed in terms of the exchange of goods, services, people and ideas in a framework of growing interdependence and a de-globalization that unfolds through regional fragmentation, overlapping regulatory orders and multiple dependencies. And, eventually, to a confrontation between the established Western international liberal order and the emergence of a potential new Eurasian order, that does not respond to liberal political values and that aims to shape new forms of global governance that are less universal and more fragmented. In any case, an emerging order that questions the possibility of maintaining the cosmopolitan or liberal institutions and norms that emerged in the previous stage and that poses risks and new challenges to the global capacity of governing the world [17].

Much of this debate in Latin America and the Caribbean is reflected in the document resulting from the colloquium organized by CRIES in September $2017^{6}$ and in the volume recently published by CRIES [23]. Most of the analysts agree that this process, although contesting institutions, rules and norms of the existing global governance, does not imply the reversibility of globalization as developed in recent decades, but its transformation. The resulting tension, in turn, has been fully evidenced in the meeting of the World Trade Organization (WTO) held in Buenos Aires in December 2017, with limited progress on

${ }^{5}$ See in this respect the chapters of the first section of [23].

${ }^{6}$ Summary of the high-level international panel "Latin America facing the crisis of globalization and the new world order" [25]. 
different issues of the previously proposed agenda, but with a clear demarcation between the more protectionist visions promoted by the Trump administration and the defense of globalization publicly declared by the Chinese government [52]. Paradoxically, the Trump's administration revisionism (and the growing protectionism of the measures it adopts) opens opportunities for China and other actors to promote a less liberal international order, based on "illiberal" normative models. However, questions remain as to whether the sustained expansion of trade, the cross-border flow of capital and the diffusion of new technologies, together with the emergence of new international actors, have transformed the global economy to a point such as to demand a reform of the existing global order more than its collapse and disappearance [24] - based on contrasting criteria and visions to those that have been previously imposed. In essence, globalization does not seem to be in question, but the global governance promoted up to now, as well as the modalities that could assume the different forms of crystallization of this globalization at the regional and national level, together with the norms and values associated with the liberal global order raise serious concerns about its future development.

\section{Reconfiguration and diffusion of world power: the emerging order}

The crisis of globalization and global governance - and eventually of multilateralism as such - are associated with the ensuing reconfiguration and diffusion of world power and the emergency of a new geopolitical chessboard with the rise of new relevant actors such as China, Russia and India [22], together with other actors that project their influence at the regional level - be it Japan and Australia or Turkey and Iran. These actors give rise to new contending global visions and narratives, which contribute to the promotion of new governance modalities and new international standards. The former "rule-makers" of the West begin to be challenged or displaced by some actors formerly identified as "rule-takers" in the international arena ${ }^{7}$ (China is often mentioned as an example, but Latin America and the Caribbean are also an illustrative case [26, p. 211]), giving rise to a new spectrum of emerging "rule makers" and, eventually, of "rule shakers" of the international system. The nascent multipolarity, specifically in this phase, is prone to policy errors, rivalries and geopolitical tensions. The development of new and multiple geopolitical narratives to read the transition, makes the emergence of a new world order more complex and its future uncertain. The coexistence of unipolar, multipolar and chaotic forms in a world in which a new world order is configured or , according to some analysts, a modality of world disorder is imposed ${ }^{8}$, contribute to create more perplexities than certainties.

Additionally, this new world order responds to a "multiplex" world [27], in which multiple actors that reflect a cultural diversity and an unequal distribution of relative

7 As Hamilton and Pelkmans point out, "for more than two centuries, either Europeans or Americans, or both together, have been accustomed to setting global rules. In the post-World War II era, the US and the evolving EU, each in its own way, has been a steward of the international rules-based order. Yet, with the rise of new powers, the resurgence of older powers and the emergence of serious challenges at home, Europeans and Americans now face the prospect of becoming rule-takers rather than rule-makers, unless they act more effectively together to ensure that high standards prevail" [57, p.3].

${ }^{8}$ In fact, Kissinger states that "there has never been a true world order. What we understand by order in our time was conceived in Western Europe almost four centuries ago, at a peace conference that took place in the Westphalian region of Germany, carried out without the participation and even the knowledge of most other continents and civilizations" [9, p. 14]. 
power compete on several simultaneous levels. Among these actors are not only national states of relative power in the international system that seek to restructure the balances of world power, configure areas of regional influence and promote their own interests, but also international organizations, transnational corporations, diverse non-state actors and geographic regions with a certain level of institutionalization [28]. This complex network of actors gives rise to the emergence of a new world that does not reflect the interests of a superior hegemonic power, nor even of a group of powers with the sufficient capacity to impose its will, in a sustained manner, on the rest, which makes it difficult to identify who will determine the new rules of the game for the system. Particularly if there is a decline of the hegemonic power of the United States at a global level vis-a-vis the emergence of China or the re-emergence and new assertiveness of Russia, Turkey, Iran and India, among other actors. In turn, the complex multilevel relations associated with this process gives rise to new ways of conceptualizing the relations between economic, political and military power, in the framework of a multidimensional chessboard [29], linked to new modalities - more complex — of regional structuring, either as new zones of influence of more powerful actors, re-emerging civilizational areas or condensations of regionalized globalization. As it was already analyzed above, global governance according to its Western and Atlanticist patterns is significantly affected by these processes.

However, in many of the studies conducted in Latin America, in the framework of this debate, the concern over US hegemonic weight seems to have been displaced by a benevolent vision of China's global projection, with a strong sino-centric emphasis. Undoubtedly, the crisis, the fragmentation and restructuring of the US elite since the Trump presidency and the very personality of the US president, with all its contradictions and ambiguities, contrasts with the coherence of the Chinese elite around the leadership of Xi Jinping and the PCCH [53], or the political model imposed by Vladimir Putin [30], but also shows that not only the US is undergoing a transformation - internal and in terms of its global projection - but also the world as a whole is living an evolution that imposes changes to the order established by the 1945 rules [31] and, eventually, by the globalization developed since the seventies. In fact, these changes put at stake the stability of the world order and the legitimacy of the established norms [9, p.20].

However, in essence, if the world is changing, it is because not only states, but a multiplicity of actors - including TNCs - are faced with the opportunity to conceptualize or re-conceptualize their vision of it, to endow this vision of a strategy and a consistent narrative and to develop it according to a cognitive map based on their interests, generally rooted in their region [28], in a way similar to how an Atlanticist ethnocentric narrative emerged at the time, founding the international liberal order based on Western liberal values.

\section{Contending geopolitical narratives}

On the global level, the narratives that prevailed in previous decades were characterized by a bipolar narrative during the Cold War that reflected the balance of forces between the US and the USSR; a unipolar narrative after the implosion of the latter with the imposition of the hegemony of the US with the support of its Western allies, and the more recent emergence of a multipolar narrative - prevalently economic but increasingly geopolitical. Within the framework of the latter, the respective elites have developed new narratives, frequently accentuating the importance of the core of regional 
dynamism, without rejecting the processes of globalization and opening the way to a regionalized globalization. The narratives themselves, are basically conceptual road maps for the search of strategic objectives of these elites - political, economic and military - in a changing world.

Therefore, after an Atlanticist narrative consolidated through decades has emerged a narrative of the Asia Pacific - with outstanding elements such as the ascendant and predominant role of China as an agent of change - "the Chinese way", "the Chinese dream", "the Chinese solution and wisdom" [54] — in the region in the context of the already mentioned shift from the Atlantic and the emphasis on "an Asia for Asians" that generates its own tensions and conflicts; several versions of a Eurasian narrative, with different cultural and identity nuances and visions and in line with the current strategic convergence of China and Russia, and a more reactive narrative of the Indo-Pacific promoted by the US, India, Japan and Australia that, despite their strong economic ties with China, perceive a threat not only to their influence and to maritime routes in Southeast Asia and the Pacific, but also to their economic and political models. The emergence of a new Eurasian narrative anchored on the circumstantial strategic convergence of China and Russia with the support, among others, of the Central Asia nations through several regional mechanisms such as the Eurasian Economic Union, the Shanghai Cooperation Organization and the recently launched initiative, is leading some analysts to argue that Atlantic dominance is not only wearing down but is going to be displaced by an Eurasian Century. In this context, is gaining momentum the perception of the emergence of a new post-Western world order, increasingly multipolar and polycentric, with the already mentioned multiplex dynamics and the emergence of new standards and rules arising from the tension between Western and non-Western ideas and values. In fact, we are facing a process of transition towards a genuinely multi-polar world - not only in economic but also geopolitical terms - within the framework of the configuration of a global agenda that is still not clearly reflected in multilateral organizations and that, on the other hand, is shaping a mixed system in which centrally planned economies coexist with more open economies, generating a more diversified social order that operates in different ways in different regions and nations around different priorities and issues of the global agenda [32]. In any event, a world order that is not so liberal. While Western values permeate this world on a global scale, the established institutional liberal order begin to adapt and to coexist with different domestic political systems and with different regional and global strategies [33], within the framework of narratives that are associated with distinctive geoeconomic and geopolitical visions and objectives.

\section{Global changes: the challenges for Latin America and the Caribbean}

Within the favorable environment of the commodities boom and the rise to power of leftist and populist governments and after the deployment of post-liberal [34; 35] or post-hegemonic attempts of regionalism [36;37] in the preceding decade, a substantive new situation emerge in the region. This situation not only occurs in the context of a reconfiguration of the regional political map, but under the impact of significant exogenous factors linked to the current transition of the global order ${ }^{9}$. The emerging design of a

\footnotetext{
${ }^{9}$ See in this regard Vigevani and Magnotta [58], Ríos [59] and Ayuso and Gratius [60].
} 
new global map of the cores of economic and military power, particularly around the emergence of new regional powers often legitimated by their own narratives, is becoming a key challenge for Latin America and the Caribbean. While the global liberal order is being contested or re-examined, the reconfiguration of global and regional powers will have an effect of crucial importance for the region in its search of a more effective inclusion in the international system in a difficult and complex environment. The development of a period of low growth, low integration, weak leadership, lower levels of agreement and higher levels of pragmatism, in a more atomized region with limited convergences [38, p. 161; 39$, p. 7$]^{10}$ questions the previously developed modalities of a "sui-generis" regionalism [40], and demands a clearer and collective view of a roadmap to achieve inclusion in the international system.

Paradoxically, while the narrative of post-hegemonic or post-liberal regionalism privileged inter-governmental political agreements, the role of the State over the market, and the search for new models of development, the new regional conjuncture, within the framework of the persistence of the region's asymmetric relations with the most powerful players in the emerging global order, tends to privilege a weakening of statism and the restoration of neoliberal policies and the importance of the market, accepting and adapting the values of global governance imposed by the West.

Despite the significant presence of Latin America and the Caribbean in the institutions of international governance - economic (G20, OECD), financial (IMF and World Bank at the global level, IDB and CAF at the regional level) and political (UN) [41, p. 55], the fragmentation of the region when dealing with the international system is striking. Particularly among countries whose "public policies and international action are marked by a model of open nationalism and horizontal governance" (such as Argentina, Brazil, Chile, Colombia, México y Perú, among others), and those where "still prevail a closed nationalism combined with a strong predominance of the State and of a hierarchical dirigisme" (Bolivia, Nicaragua, Cuba, Venezuela) [41, p. 59]. Although this division is not decisive and show significant nuances, the current trend points to a serious crisis of regionalism and to the dilution of the so-called "challenging Latin American regionalism" [42] and of South-South cooperation as they were promoted in the previous decade [43, p.64]. In this regard, attempts by the "challenging regionalism" were not able to break their complementary role with globalization and its benign or pernicious effects. The international economic context continues to build and to determine the relations and consequently the strategies for insertion of Latin America and the Caribbean in the world, recreating complex linkages between the simultaneous and interwoven processes of globalization and regionalization [21, p. 117]. However, the transformations that the globalization process currently undergoes, particularly in relation to the deceleration of international trade and the increase of protectionism, according to some authors, could open new opportunities for the region [45, p. 19]. In this regard, some analysts do not hesitate to offer a more optimistic view of the situation, by pointing out that "Latin American multilateralism, far from being downcast $[\ldots]$ shows unsuspected vigor and

${ }^{10}$ Frenkel and Comini oppose two opposing poles in the region - that of a vision that raises the need to deepen the existing global liberal order, favoring and deepening various aspects of the globalization process, confronted with an "anti-globalist" vision, which identifies globalization as a system "made to measure for large corporations" that Bremmer recreates in his latest book about the winners and losers of the globalization process and the political repercussions of this opposition. 
integrity and even projects itself outside the region with a significant capacity to summon and unite wills that few observers would have predicted him" [46, p. 8].

Nevertheless, taking into account its structural vulnerability in a multipolar world, in its attempt to "return to the world" or to insert itself more favorably in the international system, there is no doubt that since 2013 Latin America is facing a more difficult and uncertain global scenario. The gradual reorientation of the Chinese economy towards a growth model more focused on the development of the domestic market, together with the slow recovery and weak growth of the advanced economies mark the potential limits of a model of international insertion based on exports to Asia. The stalemate in the negotiations of the World Trade Organization (WTO) and in the subsequent "megaregional" negotiations of the Transpacific Agreement (TPP) and the Agreement on Trade and Transatlantic Investment (TTIP) threatens the whole region in terms of the potential imposition of more demanding norms and standards and of the diversion of trade and investment. The partial derailment of these agreements since 2016, with the rise of protectionist forces or of the frank rejection of free trade in the United States and the EU, and the strengthening of state corporations, does not imply, however, a more favorable scenario, since it poses risks of greater protectionism and economic nationalism, particularly for Latin American countries that are more open to globalization through free trade agreements with the US and the EU.

As an analyst [47] rightly points out these events should not be seen as mere shortterm phenomena. On the contrary, they are the expression of a systemic change of what can be interpreted as a crisis of transition of globalization and of the hegemonic model on which it has been sustained. This crisis of hegemony can open a more uncertain and unpredictable period, in which the certainties of the previous stage cannot be taken for granted, as in the case of the rapid growth of China and other emerging countries; the anchoring of globalization and of liberal internationalism in US hegemony; Atlanticism as the pivot of Western security and global governance; the strengthening of liberal democracy, the ruling parties and elites of the Western world, or the crucial role of multinational corporations. As already mentioned, all of these assumptions are currently under scrutiny and raise fundamental questions about the future of global governance.

Within this context, all the actors of the region and the region as a whole will have to assess these new scenarios and their short and long-term implications for a better international insertion vis-a-vis a global scenario of systemic instability, accelerated changes and greater geopolitical risk. However, particularly in South America, the decline of posthegemonic and postliberal regionalism cannot be taken as a fait accompli, "although the stage of greater politicization of pan-Latinoamericanism and anti-Americanism, appears to have diminished" [48, p. 126].

The Latin American narratives that have developed in the last decades - from open regionalism to post-liberal or post-hegemonic regionalism - have crystallized in weak institutional forms and limited scope in their capacity to generate a regional insertion in the international system. However, beyond their critical views, most of these narratives, additionally to promoting eventually greater autonomy and diversification of the foreign policies of the countries of the region, paradoxically have not questioned the international liberal order, as evidenced by the largely persistent alignment of Latin American and Caribbean countries with Western countries in voting in the framework of the UN (with possible exceptions in certain cases such as Cuba and Venezuela), confirming that 
notwithstanding the last decade changes the region tend to persist in its role of "extreme West" as opportunely pointed out by Rouquié [49]. In essence, most governments of the region do not put in question Western values of the existing international order particularly with regard to democracy, human rights, international law and norms, and economic liberalization - and actively participate in global governance bodies that emerge from that same liberal order.

Additionally, the region - despite its atomization and heterogeneity — has a series of important assets for this participation that - beyond its economic insertion in the international system - can facilitate a more active role in it. One of these assets refers to the region as a "zone of peace", with a substantial reduction of intra- and inter-state conflicts, a consistent adherence to nuclear non-proliferation and the establishment of regional mechanisms - basically through the creation of "Groups of friendly countries" from Contadora and the Rio Group to UNASUR and the Lima Group — that despite a performance with ups and downs have contributed to the development of mechanisms for conflict resolution and peace-building [6] and regional governance [50].

Based on a predominantly internal dynamic nurtured by the counterpoint between two historically rooted legal traditions - one that prioritize national sovereignty and nonintervention, and the other that has contributed to a significant development of human rights - Latin America has been able to develop a series of endogenous norms that turn it into a "rule maker" towards the region and that could eventually be projected - through a more proactive role - towards a broader sphere if it could reach a regional consensus on initiatives aimed at global governance ${ }^{11}$. As Kacowitz [6] points out, regionally Latin America and the Caribbean, despite their peripheral situation in global affairs, have managed to build a highly developed and sophisticated system of institutions and international law, including a series of regional norms that have regulated both his internal conduct and his international behavior. In this regard, perhaps the scarcely highlighted inter-American human rights system - that has transcended the borders of the region to become a transnational regime with both regional and international impact - has become a reference in the regional context (perhaps in spite of the OAS), below the radar of inter-state regional diplomacy [51, p. 234].

Beyond some sporadic cases of "rule breakers" 12 , perhaps the current global transition situation, both geo-economically and geopolitically, could open the doors for a more proactive role of the region in various multilateral mechanisms - from the UN to the G20 - with a more assertive presence in the promotion of rules of the game more in line with its inexorably Western legal and cultural heritage, but from a perspective that does not limit or reduce the autonomy that has been achieved so far.

In this sense, the tectonic movements through which the international system is crossing can become a magnificent opportunity to build - both bilaterally and multilaterally (as for example, in the case of the reactivation of Mercosur and its convergence with the Pacific Alliance, along with the advance of the agreement with the EU) - potential consensus for a new Atlantic network and for a more active collective

11 Possibly the next summit of the G20 in Buenos Aires constitutes a crucial challenge for the articulation of joint positions among the three Latin American members - Mexico, Brazil and Argentina, which, at the same time, constitute fundamental referents to advance in the construction of a new architecture of regional governance.

12 As the current case of Venezuela illustrates. 
insertion at a global level. Simultaneously, the new opportunities open by global changes can contribute to the construction of common spaces which can become platforms based on an agenda of cross-cutting issues - such as technological innovation, connectivity and infrastructure - that go beyond the conventional ones, taking advantage of the diversification of relationship patterns with the various actors of the international system, beyond the Atlantic framework. In fact, the Inter-American Development Bank (IDB) has recently proposed the creation of a free trade area for all of Latin America and the Caribbean, with Mexico, Brazil and Argentina acting as a "gravitational force" to drag the other countries, taking advantage of the convergence between Mercosur and the Pacific Alliance [55, p. 15; 56, p. 37].

While the narrative of post-liberal or post-hegemonic regionalism developed at the beginning of this century has shown signs of exhaustion, Latin America and the Caribbean are going through a complex process of reassembling their abilities in a collective search - under new parameters - of an international insertion and of a joint narrative that legitimizes it. In essence, a strategic insertion of the region demands both the need to manage the new forms of globalization and the geopolitical changes on the global level [14, p.62], as well as shaping a more proactive attitude in governance and the global agenda and forging a unifying narrative. These aspirations, complex in itself, are associated with a fragmented and diverse perception of the current international and regional dynamics and by domestic constraints. However, it compels the need to generate conceptual inputs to contribute to recompose or to articulate a vision of the strategies required for a better insertion of the region in the changing arena of the international system and possibly of the necessary shaping of tools and mechanisms to propel them in a collective and inclusive way. As an analyst points out "it is possible to conclude that regionalism in Latin America is still in a phase of construction, very dependent on changes in the international system in general and the constant changes in the internal politics of the countries most committed to regional governance" $[49$, p.25]. The global changes underway are, in this context, particularly challenging for a region that use to be peripheral to the greater world trends and dynamics but has the necessary political, normative and legal capital to play a more significant role in the current transition.

\section{References}

1. Llenderozas, E. (2018), "Una nueva lógica de poder para un mundo uestable" [A New Power Logic in a Instable World], La Nación, no. 4, available at: https://www.lanacion.com.ar/opinion/una-nueva-logicade-poder-para-un-mundo-inestable-nid2132397 (accessed: 09.11.2018).

2. Sanahuja, J. A. (2017), "Crisis de globalización y hegemonía: un escenario de cambio estructural para Cuba y Latinoamérica y el Caribe" [Globalization and Hegemony Crisis: A Scenario for Structural Change for Cuba and Latin America and the Caribbean], Pensamiento Propio, no. 45, año 22, CRIES, Buenos Aires, pp. 165-203.

3. Heine, J. and Thakur, R. (2011), "Introduction, Globalization and Transnational Uncivil Society" in Heine, J. and Thakur, R. (eds), The Dark Side of Globalization. The United Nations University Press, Tokyo.

4. Bremmer, I. (2018), Us vs. Them. The Failure of Globalization, Portfolio/Penguin, New York, USA.

5. World Commission on the Social Dimension of Globalization (2004), A Fair Globalization: Creating Opportunities for All, International Labour Organization (ILO), Geneva, Swiss.

6. Kacowicz, A. (2018), "Regional Governance and Global Governance: links and Explanations", Global Governance, no. 24, pp. 61-79.

7. Gordenker, G. and Weiss, T. (1996), "Pluralizing Global Governance: Analytical Approaches and Dimensions" in Gordenker, G. and Weiss, T. (eds), NGOs, The UN 6 Global Governance, Lynne Rienner, Boulder, USA. 
8. Legler, T. (2013) "La gobernanza global" [Global Governance], in Legler, T., Santa Cruz, A. and Zamudio, L. (eds), Introducción a las relaciones internacionales: América Latina y la política global [Introduction to International Relations: Latin America and Global Politics], México D. F., México, Oxford University Press, UK, pp. 253-282.

9. Kissinger, H. (2017), Orden mundial [World Order, Debate, Buenos Aires, Argentina.

10. Serbin, A. (2013), "Actores no estatales y política transnacional" [Non-State Actors and Transnational Politics], in Legler, T., Santa Cruz, A. and Zamudio, L. (eds), Introducción a las relaciones internacionales: América Latina y la política global [Introduction to International Relations: Latin America and Global Politics], México D. F., Oxford University Press, pp. 172-183.

11. Serbin, A. (2002), "Globalización, integración regional y sociedad civil” [Globalization, Regional Integration and Civil Society], in Oliva, C. and Serbin, A. (comps.) América Latina, el Caribe y Cuba en el contexto global [Latin America, the Caribbean and Cuba in a Global Context], CRIES, Araraquara, Brazil, pp. $20-86$.

12. Mead, W. (2014), “The Return of Geopolitics. The Revenge of the Revisionist Powers", Foreign Affairs, May-June, pp. 69-79.

13. Ikenberry, J. (2014), "The Illusion of Geopolitics”, Foreign Affairs, May/June, pp. 80-90.

14. Actis, E. and Busso A. (2016-2017), “Globalización 'descarriada' y 'regionalismo desconcertado' en la era Trump" ["Deviant globalization and 'disconcerted regionalism' in the Trump era"], Raigal, no. 3, pp. 51-64.

15. Grabendorff, W. (2018) "América Latina en la era de Trump" ["Latin America in the Trump Era"], Nueva Sociedad, no. 275, marzo-junio, pp. 47-61.

16. Held, D., McGrew, A., Goldblatt, D. and Perraton, J. (1999) Global Transformations, Stanford University Press, Stanford, USA.

17. Stephen, M. (2017) "Emerging Powers and Emerging Trends in Global Governance", Global Governance: A Review of Multilateral and International Organizations, July-September, vol. 23, no. 3, pp. 483-502.

18. Serbin, A. and Serbin Pont, A (2015), "Latin America and the Responsibility to Protect: Divergent Views from the South?”, Pensamiento Propio, no. 41, vol. 20, January-June, pp. 11-33.

19. "What Was the Liberal Order? The World We May Be Losing" (2017), Foreign Affairs, March.

20. Luce, E. (2017), The Retreat of Western Liberalism, Atlantic Monthly Press, New York, USA.

21. Kacowizc, A. (2008), "América Latina en el mundo: globalización, regionalización y fragmentación", ["Latin America in the World: Globalization, Regionalization and Fragmentation"], Nueva Sociedad, no. 214, marzo-abril, pp. 112-123.

22. Oropeza García, A. (2017), Del Atlántico al Pacífico. Reconstruyendo el orden global [From Atlantic to Pacific: Rebuilding Global Order], Cámara de Diputados, México D. F., México.

23. Serbin, A. (ed.) (2018), América Latina y el Caribe frente al Nuevo Orden Mundial: Poder, globalización y respuestas regionales [Latin America and the Caribbean vis-a-vis a New Global Order: Power, Globalization and Regional Responses], Editorial Icaria-CRIES, Barcelona, Spain, Buenos Aires, Argentina.

24. Hu, F. and Spence, M. (2017), "Why Globalization Stalled and How to restart it", Foreign Affairs, vol. 96, no. 4, July/August, pp. 54-63.

25. "América Latina y el Caribe en la encrucijada de la globalización (Latin America and the Caribbean at the Crossroad of Globalization)" (2018), in Serbin A., Martinez L., Ramanzini, H. (Jr.) and Serbin Pont A. (eds), Anuario de la integración de América Latina y el Caribe 2016-2017, CRIES, Buenos Aires:, Argentina.

26. Keohane, R. (2001), "Between Vision and Reality: Variables in Latin American Foreign Policy", in Tulchin, J. and Espach, R. (eds), Latin America in the New International System, Lynn Rienner, Boulder, USA.

27. Acharya, A. (2018), The End of American World Order, Polity Press, Cambridge, UK.

28. Hurrell, A. (2009), On Global Order. Power, Values and the Constitution of International Society, Oxford University Press, Oxford, UK.

29. Brzezinski, Z. (1997), The Grand Chessboard, Penguin, New York, USA.

30. Myers, S. (2017), El nuevo zar. Ascenso y dominio de Vladimir Putin Zar [The New Rise and Dominance of Vladimir Putin], Ariel, Buenos Aires, Argentina.

31. Kochin, M. (2017), Transformations of World Order: Lessons from Kissinger and the English School, available at: https://www.academia.edu/34217184/Transformations_of_World_Orders_Lessons_from_ Kissinger_and_the_English_School (accessed: 09.11.2018).

32. Mazzar, M. (2017), “The Once and Future Order. What Comes After Hegemony", Foreign Affairs, vol. 96, no. 1, January/February, pp. 25-32.

33. Niblett, R. (2017), "Liberalism in Retreat. The Demise of a Dream", Foreign Affairs, vol. 96, no. 1, January/February, pp. 17-24. 
34. Sanahuja, J. (2012), "Regionalismo postliberal y multilateralismo en Sudamérica" [Post-Liberal Regionalism and Multilateralism in Latin America], Anuario de la integración regional de América Latina y el Caribe, no. 9, pp. 19-72.

35. Serbin, A. (2012), "Deficit democrático y participación ciudadana en el marco del regionalismo postliberal" [Democratic Deficit and Citizen's Participation Within the Framework of Post-Liberal Regionalism], in Serbin A., Martinez L., Ramanzini, H. (Jr.) and Serbin Pont A. (eds) El regionalismo postliberal en América Latina y el Caribe: nuevos actores, nuevos temas, nuevos desafíos [Post-Liberal Regionalism in Latin America and the Caribbean: New Actors, New Themes, New Challenges?]. CRIES, Buenos Aires, Argentina, pp. 73-127.

36. Riggirozzi, P. and Tussie, D. (eds) The Rise of Post-Hegemonic Regionalism in Latin America. Ddrecht: Springer, 2012.

37. Briceño-Ruiz, J. and Morales, I. (eds) Post-Hegemonic Regionalism in the Americas, Routledge, London, UK, New York, USA.

38. Merke, F. (2017), "Lo que sabemos, lo que creemos saber y lo que no sabemos de América Latina" [What we know, what we think we know, and what we don't know about Latin America], Pensamiento Propio, no. 45, enero-junio, año 22, pp. 143-163.

39. Frenkel, A. and Comini, N. (2017), "La política internacional de América Latina: más atomización que convergencia" [International Politics in Latin America: More Atomization tan Convergence?], Nueva Sociedad, septiembre-octubre, available at: http://nuso.org/articulo/la-politica-internacional-deamericalatina-mas-atomizacion-que-convergencia (accessed: 09.11.2018).

40. Serbin, A. (2010), "Los desafíos del multilateralismo" [The Challenges of Multilateralism], Anuario de la Integración de América Latina y el Gran Caribe, no. 8, pp. 7-39.

41. Malamud, C. (coord.) (2017), "Por qué importa América Latina?” [Why Latin America Matters?], Informe Elcano, no. 22, December.

42. Preciado Coronado, J. (2013), "Paradigma social en debate; aportaciones del enfoque geopolítico crítico. La Celac en la integración autónoma de América Latina" [The Social Paradigm in Question; Contributions to a Critical Geopolitical Approach], Ruiz Uribe, M. N. (coord.), América Latina en la crisis global: Problemas y desafíos [Latin American in the Global Crisis: Problems and Challenges], Clacso-AlasUDT, México, pp. 25-50.

43. Svampa, M. (2017), “Cuatro claves para leer América Latina” [Four Clues for Reading Latin America], Nueva Sociedad, no. 268, marzo-abril, pp. 50-64.

44. Kacowizc, A. (2018), "Learning about the World (Order) from Latin American experience (and vice versa)", in Serbin, A. (ed.) América Latina y el Caribe frente al Nuevo Orden Mundial: Poder, globalización y respuestas regionales, Editorial Icaria, Barcelona, Spain, CRIES, Buenos Aires, Argentina, pp. 299-318.

45. Salama, P. (2017), "Menos globalización: marginación u oportunidad para América Latina?" [Less Globalization: Marginalization or Opportunity for Latin America], Nueva Sociedad, septiembre-octubre, available at: http://nuso.org/articulo/menos-globalizacion-marginacion-u-oportunidad-para-americalatina (accessed: 09.11.2018).

46. Heine, J. (2018), "Multilateralismo latinoamericano: de menos a más?" [Latin American Multilateralism: From Less to More?”, Foreign Affairs Latinoamérica, vol. 18, no. 2, pp. 8-13.

47. Sanahuja, J. A. (2016), "América Latina en un cambio de escenario: de la bonanza de los commodities a la crisis de la globalización" [Latin America in a Changing Scenario: From the Commodities Boom to the Globalization Crisis], Pensamiento Propio, no. 44, julio-diciembre, año 21, pp. 13-27.

48. Quirós, L. (2017), "Reconfiguración política y gobernanza regional en América Latina Hacia dónde va el regionalismo postliberal?" [Political Reconfiguration and Regional Governance in Latin America: Where the Post-Liberal Regionalism is Heading to?], Revista Andina de Estudios Políticos, vol. 7, no. 2, pp. 111-131.

49. Rouquié, A. (1989), América Latina: Introducción al extremo Occidente (Latin America: Introduction to the Extreme West), Siglo XXI, Buenos Aires, Argentina.

50. Grabendorff, W. (2015), "La gobernanza regional en América Latina: condicionamientos y limitaciones" [Regional Governance in Latin America: Constraints and Limitations], Pensamiento Propio, no. 42, julio-diciembre, Número monográfico sobre "La arquitectura de la gobernanza regional en América Latina: condicionamientos y limitaciones", pp. 9-29.

51. Engstrom, P. (2016), “The Inter-American Human Rights System and US-Latin American Relations", in Scarfi, J.P. and Tillman A. (eds) Cooperation and Hegemony in US-Latin American Relations, Palgrave Macmillan, New York, USA, pp. 209-247.

52. Rudd, K. (2018), “How Xi Jinping Views the World”, Snapshot Foreign Affairs, May 10, available at: https:// www.foreignaffairs.com/articles/china/2018-05-10/how-xi-jinping-views-world (accessed: 09.11.2018). 
53. De Graaff, N. and Apeldoorn, B. van (2018), "US-China relations and the liberal world order: contending elites, colliding visions?", International Affairs, vol. 94, no. 1, pp. 113-132.

54. "China defines itself as an 'alternative model' for the world" (2017), Russia Today. November 8, available at: https://actualidad.rt.com/actualidad/254474-china-modelo-alternativo-desarrollo-mundo (accessed: 09.11.2018).

55. "The IDB proposes a free trade area in all of Latin America" (2018), La Nación. May 2.

56. "Latin America loses 11,300 million each year as it does not have a single trade agreement" (2018), El País. May 30.

57. Pelkmans, J. and Hamilton, Daniel S. (2015), "Rule-makers or rule-takers? An introduction to TTIP”, in Pelkmans, J. and Hamilton, Daniel S. (eds), Rule-Makers or Rule-Takers? Exploring the Transatlantic Trade and Investment Partnership, Rowman and Littlefield International, London.

58. Vigevani, T. and Magnotta, F. (2016), "Os atores externos: Agendas e estrategias dos Estados Unidos para a América Latina”, Pensamiento Propio, no. 44, año 21, pp. 179-215.

59. Ríos, X. (2016), "China América Latina y Caribe: otra relación para otros futuros", Pensamiento Propio, no. 44, año 21, pp. 217-247.

60. Ayuso, A. and Gratius, S. (2016), "América Latina y Europa: ¿Repetir o reinventar un ciclo?", Pensamiento Propio, no. 44, año 21, pp. 249-292.

Received: November 11, 2018

Accepted: February 14, 2019

Author's information:

Andrés Serbin — PhD, Professor, Coordinadora Regional de Investigaciones Económicas y Sociales; aserbin@cries.org 